\title{
Bacillus endoradicis sp. nov., an endophytic bacterium isolated from soybean root
}

Correspondence
Wen Feng Chen
chenwf@cau.edu.cn or
cauchenwenfeng@gmail.com
Yun Zeng Zhang, ${ }^{1}$ Wen Feng Chen, ${ }^{1}$ Mao Li, ${ }^{1}$ Xin Hua Sui,
Hong-Can Liu, ${ }^{1}$ Xiao Xia Zhang ${ }^{3}$ and Wen Xin Chen ${ }^{1}$

${ }^{1}$ State Key Laboratory of Agrobiotechnology and Department of Microbiology and Immunology,
College of Biological Sciences, China Agricultural University, Beijing 100193, PR China
${ }^{2}$ Institute of Microbiology, Chinese Academy of Sciences, Beijing 100101, PR China
${ }^{3}$ Agricultural Cultural Collection of China, Institute of Agricultural Resources and Regional Planning,
Chinese Academy of Agricultural Sciences, Beijing 100081, PR China

A Gram-positive, aerobic, motile rod, designated strain CCBAU $05776^{\top}$, was isolated from the inner tissues of a healthy soybean (Glycine max L.) root collected from an agricultural field in the countryside of Shijiazhuang city, Hebei Province, China. Phylogenetic analysis of the 16S rRNA gene indicated that this strain was most closely related to Bacillus muralis LMG $20238^{\top}$ and Bacillus simplex NBRC $15720^{\top}$ with similarity of $96.5 \%$ and $96.3 \%$, respectively, lower than the suggested threshold $(97.0 \%)$ for separating bacterial species. In phenotypic characterization, the novel strain differed from the two most related species in that it did not hydrolyse casein or starch but could grow on MacConkey agar. It grew between 15 and $45{ }^{\circ} \mathrm{C}$ and tolerated up to $7 \% \mathrm{NaCl}$ $(\mathrm{w} / \mathrm{v})$. Strain CCBAU $05776^{\top}$ grew in media with $\mathrm{pH} 5.5$ to 10 (optimal growth at $\mathrm{pH} 7.0-8.0$ ). The predominant cellular fatty acids were iso- $\mathrm{C}_{15: 0}(40.81 \%)$ and $\mathrm{C}_{16: 1} \omega 7 \mathrm{c}$ alcohol (10.61\%). The predominant isoprenoid quinone was menaquinone 7 (MK-7). The cell-wall peptidoglycan contained meso-diaminopimelic acid. The major polar lipids were diphosphatidylglycerol and phosphatidylglycerol. The DNA G $+\mathrm{C}$ was $40.8 \mathrm{~mol} \%\left(T_{\mathrm{m}}\right)$. DNA-DNA relatedness of the novel isolate with $B$. muralis and $B$. simplex was $42.4 \%$ and $32.7 \%$, respectively. Based upon the consensus of phylogenetic and phenotypic analyses, strain CCBAU $05776^{\top}$ represents a novel species within the genus Bacillus, for which the name Bacillus endoradicis sp. nov. is proposed.

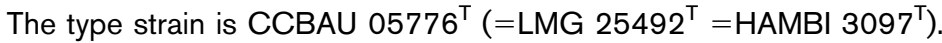

Many species of the genus Bacillus are endophytes frequently isolated from the inner tissues of different plants, such as Bacillus subtilis, Bacillus thuringiensis and Bacillus pumilus strains in soybean nodules (Bai et al., 2002; Li et al., 2008), B. subtilis in wheat (Liu et al., 2009), B. subtilis, B. pumilus and Bacillus sp. in maize (Rai et al., 2007; Rijavec et al., 2007) and Bacillus endophyticus and Bacillus sp. in cotton (Rajendran \& Samiyappan, 2008; Rajendran et al., 2007; Reva et al., 2002). These endophytic bacteria can be pertinent to plant growth by suppressing pathogens (Liu et al., 2009; Senthilkumar et al., 2009) or producing phytohormones (Arkhipova et al., 2005). Some endophytic species of the genus Bacillus can enhance the nodulation of rhizobia on legumes when they are coinoculated (Bai et al., 2002; Rajendran et al., 2008).

The GenBank/EMBL/DDBJ accession number for the 16S rRNA gene sequence of strain CCBAU $05776^{\top}$ is GU434676.

Three supplementary figures are available with the online version of this paper.
In our investigation of endophytic bacterial diversity in soybean roots, an aerobic Gram-positive bacterium designated strain CCBAU $05776^{\mathrm{T}}$ was isolated and identified as a distinct lineage in the genus Bacillus by phylogenetic screening. To clarify its taxonomic position, this strain was characterized phenotypically, genomically and phylogenetically. The results suggested that strain CCBAU $05776^{\mathrm{T}}$ represents a novel species of the genus Bacillus.

Soybean roots [Glycine $\max$ (L.) Merr. 'Jidou no.17'] were collected from an agricultural field in the countryside of Shijiazhuang city $\left(38^{\circ} 03^{\prime} \mathrm{N} 114^{\circ} 29^{\prime} \mathrm{E}\right)$, Hebei Province, China. The roots were pulled out from soil and transported on ice to the laboratory on the day of collection. In the laboratory, attached soil was removed from the roots by washing under running tap water and epiphytes were eliminated by surface disinfection through immersion in $95 \%(\mathrm{v} / \mathrm{v})$ ethanol for $30 \mathrm{~s}$ and in $0.2 \%(\mathrm{w} / \mathrm{v}) \mathrm{HgCl}_{2}$ solution for $4 \mathrm{~min}$, followed by six rinses in sterilized distilled water. The disinfection efficiency was checked by plating aliquots of the sterile distilled water used in the 
final rinse onto nutrient agar [NA; containing $0.5 \%$ peptone, $0.3 \%$ beef extract, $0.5 \% \mathrm{NaCl}$ and $1.5 \%$ agar (all w/v), $\mathrm{pH}$ adjusted to 6.8 at $25^{\circ} \mathrm{C}$ ], which were then incubated at $28{ }^{\circ} \mathrm{C}$ for 3 days. To isolate the endophytes, one gram of surface-sterilized roots was ground vigorously in $9 \mathrm{ml} 0.85 \% \mathrm{NaCl}$ solution for $5 \mathrm{~min}$ and decimal dilutions up to $10^{-4}$ were prepared. Aliquots of $0.1 \mathrm{ml}$, in duplicate, from each of the last three dilutions were spread on NA medium and incubated for 3 days at $28{ }^{\circ} \mathrm{C}$. Single colonies were picked up and purified by streaking on the same medium three times.

To determine the taxonomic status of the isolates rapidly, amplification and sequencing of the 16S rRNA gene were carried out using primers $27 \mathrm{~F}$ and 1492R (Ritchie et al., 1997). A partial 16S rRNA gene sequence (1398 bp) was obtained from strain CCBAU $05776^{\mathrm{T}}$, which showed close relationships to species of the genus Bacillus in MEGABLAST searches using the NCBI and RDP databases. Sequence similarities of strain CCBAU $05776^{\mathrm{T}}$ with the most closely related species were calculated using the EzTaxon server (Chun et al., 2007) as $96.5 \%$ with B. muralis LMG $20238^{\mathrm{T}}$, followed by $96.3 \%$ with B. simplex NBRC $15720^{\mathrm{T}}, 96.2 \%$ with Bacillus butanolivorans $\mathrm{K}^{\mathrm{T}}$, $96.1 \%$ with Bacillus pocheonensis Gsoil $420^{\mathrm{T}}$ and $96.0 \%$ with Bacillus asahii $\mathrm{MA} 001^{\mathrm{T}}$. The sequences were aligned with sequences of related strains extracted from the RDP database using CLUSTAL X version 2 software (Larkin et al., 2007). The phylogenetic tree reconstructed by MEGA 4 software (Tamura et al., 2007) using the neighbour-joining method (Saitou \& Nei, 1987) with the model of Jukes \& Cantor (1969), and bootstrapped with 1000 pseudosamples (Felsenstein, 1985) revealed that strain CCBAU $05776^{\mathrm{T}}$ occupied a distinctive position within the group of species mentioned above, except for B. pocheonensis (Fig. 1). A phylogenetic tree based on the maximum-likelihood algorithm was also reconstructed (Supplementary Fig. S1 available in IJSEM Online) using the PhyML program, version 3.0 (Guindon \& Gascuel, 2003) and showed phylogenetic relationships similar to those in the neighbour-joining tree. Since strain CCBAU $05776^{\mathrm{T}}$ had $16 \mathrm{~S}$ rRNA gene sequence similarities lower than the threshold (97\%) for delineating bacterial species (Stackebrandt \& Goebel, 1994), this strain was further characterized to clarify its species identity.

Cell morphology of strain CCBAU $05776^{\mathrm{T}}$ was investigated with scanning electron microscopy after cultivation on NA plates at $28{ }^{\circ} \mathrm{C}$ for $24 \mathrm{~h}$. Cell motility and aerotactic ability were determined by observing the growth spread of cells in a test tube containing semi-solid NA medium. To detect the endospore morphology, the strain was grown on PCA medium (containing $0.5 \%$ peptone, $0.25 \%$ yeast extract, $0.1 \%$ glucose, $1.5 \%$ agar) at $28{ }^{\circ} \mathrm{C}$ for $36 \mathrm{~h}$, and was then stained as described by Bartholomew \& Mittwer (1950). Cells of this strain were rods $(0.7-0.9 \mu \mathrm{m}$ wide and 1.9$2.7 \mu \mathrm{m}$ long) (Supplementary Fig. S2). The strain is motile and aerobic as determined by observing the growth extending from an inoculating stab line in semi-solid NA medium and gathering at the top of the test tube in order to absorb maximal oxygen. Cells produced ellipsoidal spores located centrally or subterminally in swollen sporangia after being cultivated for more than $24 \mathrm{~h}$.

Phenotypic and biochemical properties of strains CCBAU $05776^{\mathrm{T}}$, B. muralis LMG $20238^{\mathrm{T}}$, B. simplex LMG $11160^{\mathrm{T}}$ and $B$. asahii JCM $12112^{\mathrm{T}}$ were determined using the methods described by Dong \& Cai (2001). Salt tolerance

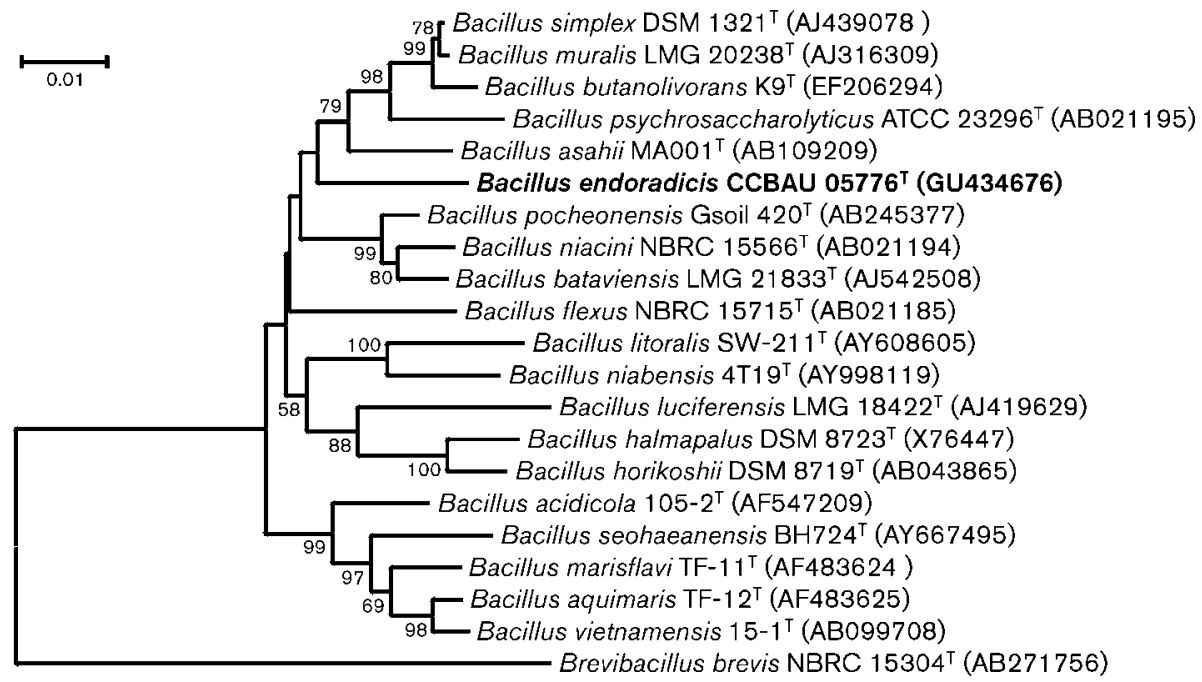

Fig. 1. Phylogenetic tree derived from 16S rRNA gene sequences of strain CCBAU $05776^{\top}$ and other members of the genus Bacillus using the neighbour-joining method. Numbers at branching points represent percentage bootstrap values obtained (based on 1000 pseudosamples; only those greater than $50 \%$ are shown). Bar, $0.01 K_{\text {nuc }}$ unit, representing 0.01 inferred substitutions per nucleotide position. 
was tested at $0,0.5,1,2,3,4,5,7$ and $10 \%(\mathrm{w} / \mathrm{v}) \mathrm{NaCl}$ in nutrient broth (NB; NA medium omitting the agar). The temperature range for growth was tested at $4,10,15,20,28$, 37,45 and $55{ }^{\circ} \mathrm{C}$. The $\mathrm{pH}$ range for growth in $\mathrm{NB}$ was tested from $\mathrm{pH} 5.5$ to 10.0 in increments of $0.5 \mathrm{pH}$ units. Catalase activity was determined by assessing bubble production in $3 \%(\mathrm{v} / \mathrm{v}) \mathrm{H}_{2} \mathrm{O}_{2}$. Growth on MacConkey agar (MAC) (20.0 g peptone, $10.0 \mathrm{~g}$ lactose, $5.0 \mathrm{~g}$ sodium chloride, $16.5 \mathrm{~g}$ agar, $0.03 \mathrm{~g}$ neutral red, $1.0 \mathrm{mg}$ crystal violet, $1 \mathrm{l}$ water) was also tested. Carbon metabolic characteristics were characterized with a Biolog GP2 MicroPlate according to the manufacturer's instructions (Biolog). All assays were performed in triplicate.

Strain CCBAU $05776^{\mathrm{T}}$ grew in NB supplemented with 0 $7 \%(\mathrm{w} / \mathrm{v}) \mathrm{NaCl}$ and optimum growth occurred in media with $0-0.5 \% \mathrm{NaCl}$. Optimal growth was observed at $\mathrm{pH} 7.0-8.0$. Weak growth occurred at $\mathrm{pH} 10.0$ and no growth occurred at $\mathrm{pH}$ 5.5. Growth was observed at temperatures between 15 and $45{ }^{\circ} \mathrm{C}$, with optimal growth between 28 and $37{ }^{\circ} \mathrm{C}$. The physiological and biochemical properties useful for differentiation of strain CCBAU $05776^{\mathrm{T}}$ from its closest phylogenetic neighbours are listed in Table 1 . In all tests, B. muralis, B. simplex and B. asahii

Table 1. Phenotypic characteristics of strain CCBAU $05776^{\top}$ and related species

Strains: 1 , Bacillus endoradicis sp. nov. CCBAU $05776^{\mathrm{T}} ; 2$, B. muralis LMG $20238^{\mathrm{T}}$; 3, B. simplex LMG $11160^{\mathrm{T}}$; 4, B. asahii JCM $12112^{\mathrm{T}}$; 5, B. butanolivorans (data from Kuisiene et al., 2008); 6, B. psychrosaccharolyticus (Priest et al., 1988). Data from the present study except where indicated. +, Positive; -, negative; NG, no growth; ND, not determined; $v$, variable.

\begin{tabular}{|lcccccc|}
\hline Characteristic & $\mathbf{1}$ & $\mathbf{2}$ & $\mathbf{3}$ & $\mathbf{4}$ & $\mathbf{5}$ & $\mathbf{6}$ \\
\hline Swollen sporangia & + & + & - & - & - & + \\
Growth on MacConkey agar & + & - & - & $-*$ & - & + \\
Growth at: & & & & & & \\
$10{ }^{\circ} \mathrm{C}$ & - & + & + & - & + & + \\
$45{ }^{\circ} \mathrm{C}$ & + & - & - & + & + & $\mathrm{ND}$ \\
Growth in medium with $7 \%$ (w/v) & + & + & - & - & - & - \\
NaCl & & & & & & \\
Hydrolysis of: & & & & & & \\
Casein & & & & & & \\
Starch & - & + & + & + & - & + \\
Gelatin & - & + & + & + & - & + \\
Acid produced from: & + & + & + & - & - & + \\
Lactose & & & & & & \\
D-Mannitol & - & + & - & - & NG & - \\
D-Mannose & NG & + & + & - & - & V \\
D-Ribose & + & + & - & - & - & + \\
D-Glucose & - & + & + & ND & - & ND \\
L-Arabinose & + & + & + & - & - & + \\
& NG & + & - & - & NG & - \\
\hline
\end{tabular}

${ }^{\star}$ Data from Yumoto et al. (2004).

$\dagger$ Different from data described by Heyrman et al. (2005). showed almost the same characteristics as in previous reports (Heyrman et al., 2005; Yumoto et al., 2004).

Analysis of whole-cell fatty acids was carried out with strain CCBAU $05776^{\mathrm{T}}$ cultivated on tryptic soy agar (TSA) (containing $15 \mathrm{~g}$ tryptone, $5 \mathrm{~g}$ soytone, $5 \mathrm{~g} \mathrm{NaCl}, 15 \mathrm{~g}$ agar, 11 distilled water) at $28{ }^{\circ} \mathrm{C}$ for $24 \mathrm{~h}$. Fatty acids were prepared and identified using the standard method described by Sasser (1990). The Microbial Identification System (MIDI) with the HP 6890 GC and database TSBA6 were used for identification of peaks. Differentiating characteristics of the fatty acid profiles of strain CCBAU $05776^{\mathrm{T}}$ and related species are indicated in Table 2. Strain CCBAU $05776^{\mathrm{T}}$ had larger proportions of iso- $\mathrm{C}_{13: 0}$, iso- $\mathrm{C}_{15: 0}$ and iso- $\mathrm{C}_{17: 1} \omega 10 c$ compared with the other type strains. Strain CCBAU $05776^{\mathrm{T}}$ contained only $4.44 \%$ anteiso- $\mathrm{C}_{15}$ : 0 , which was greatly different from its close relatives $B$. muralis LMG $20238^{\mathrm{T}}$ and B. simplex LMG $11160^{\mathrm{T}}$.

Cellular menaquinones were isolated using the method of Collins (1985) and separated by HPLC (Kroppenstedt, 1982), and the results showed that MK-7 was the major menaquinone component of strain CCBAU $05776^{\mathrm{T}}$ in agreement with the description of the genus Bacillus. Polar lipids were extracted as described by Minnikin et al. (1979) and were then identified by two-dimensional TLC. The major polar lipids presented in strain CCBAU $05776^{\mathrm{T}}$ were diphosphatidylglycerol and phosphatidylglycerol (Supplementary Fig. S3). The isomer type of the diamino acid of the peptidoglycan was determined using the method described by Schleifer \& Kandler (1972). Strain CCBAU $05776^{\mathrm{T}}$ contained meso-diaminopimelic acid as its diagnostic diamino acid.

Total DNA of strain CCBAU $05776^{\mathrm{T}}$ was extracted and purified according to the method of Marmur (1961). The DNA $\mathrm{G}+\mathrm{C}$ content of strain CCBAU $05776^{\mathrm{T}}$ was $40.8 \mathrm{~mol} \%\left(T_{\mathrm{m}}\right)$ determined as described by De Ley

Table 2. Comparison of the fatty acid profiles of strain CCBAU $05776^{\top}$ and related species of the genus Bacillus

Strains: 1 , B. endoradicis sp. nov. CCBAU $05776^{\mathrm{T}} ; 2$, B. muralis LMG $20238^{\mathrm{T}}$; 3, B. simplex LMG $11160^{\mathrm{T}}$; 4, B. asahii JCM $12112^{\mathrm{T}} ; 5$, B. psychrosaccharolyticus LMG $9580^{\mathrm{T}}$. ND, not detected.

\begin{tabular}{|c|c|c|c|c|c|}
\hline Fatty acid & 1 & 2 & 3 & 4 & 5 \\
\hline iso- $\mathrm{C}_{13: 0}$ & 2.59 & 0.11 & 0.07 & 0.92 & 0.55 \\
\hline iso- $\mathrm{C}_{14: 0}$ & 11.87 & 2.39 & 19.49 & 42.80 & 2.54 \\
\hline $\mathrm{C}_{14: 0}$ & 1.57 & 0.64 & 0.81 & 3.90 & 0.56 \\
\hline iso- $\mathrm{C}_{15: 0}$ & 40.81 & 15.24 & 10.25 & 18.24 & 20.45 \\
\hline anteiso- $\mathrm{C}_{15: 0}$ & 4.44 & 64.73 & 36.84 & 4.85 & 52.41 \\
\hline $\mathrm{C}_{16: 1} \omega 7 c$ alcohol & 10.61 & 2.11 & 11.52 & 8.19 & 1.03 \\
\hline iso- $\mathrm{C}_{16: 0}$ & 7.81 & 0.97 & 9.93 & 1.99 & 0.27 \\
\hline $\mathrm{C}_{16: 1} \omega 11 c$ & 5.22 & 2.12 & 2.18 & 5.39 & 0.52 \\
\hline $\mathrm{C}_{16: 0}$ & 4.24 & 1.79 & 2.83 & 4.60 & 5.96 \\
\hline iso- $\mathrm{C}_{17: 0}$ & 1.40 & 0.78 & 0.73 & $\mathrm{ND}$ & 0.51 \\
\hline iso- $\mathrm{C}_{17: 1} \omega 10 c$ & 2.72 & 1.72 & 0.60 & 0.59 & 1.14 \\
\hline
\end{tabular}


(1970). In DNA-DNA hybridization studies using the initial renaturation-rate technique (De Ley et al., 1970), strain CCBAU $05776^{\mathrm{T}}$ showed DNA-DNA relatedness much lower than the threshold $(70 \%)$ for differentiating species (Wayne et al., 1987) with B. muralis $(42.4 \%$ ) and $B$. simplex $(32.7 \%)$, respectively, confirming that strain CCBAU $05776^{\mathrm{T}}$ represents a distinct genomic species within the genus Bacillus.

Based on the consensus of results mentioned above and the minimal standard for describing new taxa of aerobic, endospore-forming bacteria (Logan et al., 2009), it can be firmly concluded that strain CCBAU $05776^{\mathrm{T}}$ represents a novel species within the genus Bacillus, for which the name Bacillus endoradicis sp. nov. is proposed.

\section{Description of Bacillus endoradicis sp. nov.}

Bacillus endoradicis (en.do.ra'di.cis. L. prep. endo in, within; L. n. radix-icis a root; N.L. gen. n. endoradicis of the inside of a root).

Cells are aerobic, Gram-positive, rod-shaped, 0.7-0.9 $\mu \mathrm{m}$ in diameter and 1.9-2.7 $\mu \mathrm{m}$ in length. They bear an ellipsoidal endospore which lies in central or subterminal position. After 2 days at $28{ }^{\circ} \mathrm{C}$ on NA, colonies are transparent and white with a slightly irregular edge. Cells usually occur singly or in pairs, occasionally in chains. Optimal growth at $28-37{ }^{\circ} \mathrm{C}, \mathrm{pH} \quad 7.0-8.0$ and with $0-0.5 \% \mathrm{NaCl}$ in nutrient broth. Catalase-positive, and does not hydrolyse casein or starch. Citrate is not utilized. Indole production and Voges-Proskauer test are negative. Oxidase-negative. Nitrate reduction is positive. Assimilates (in Biolog GP2 MicroPlate) $\alpha$-cyclodextrin, dextrin, $N$-acetyl-D-glucosamine, D-fructose, $\alpha$-D-glucose, maltotriose, D-mannose, 3methyl glucose, D-psicose, D-ribose, salicin, $\alpha$-ketovaleric acid, L-glutamic acid, glycyl L-glutamic acid, L-pyroglutamic acid, adenosine, 2'-deoxyadenosine, inosine, thymidine, uridine, adenosine $5^{\prime}$-monophosphate and uridine $5^{\prime}$ monophosphate. Does not assimilate $\beta$-cyclodextrin, glycogen, inulin, mannan, Tween 40 , Tween $80, \mathrm{~N}$-acetyl$\beta$-D-mannosamine, amygdalin, L-arabinose, D-arabitol, arbutin, cellobiose, L-fucose, D-galactose, D-galacturonic acid, gentiobiose, D-gluconic acid, myo-inositol, $\alpha$-lactose, lactulose, maltose, D-mannitol, melezitose, melibiose, methyl $\alpha$-D-galactoside, methyl $\beta$-D-galactoside, methyl $\alpha$ D-glucoside, methyl $\beta$-D-glucoside, methyl $\alpha$-D-mannoside, palatinose, raffinose, L-rhamnose, sedoheptulosan, D-sorbitol, stachyose, sucrose, D-tagatose, trehalose, turanose, xylitol, D-xylose, acetic acid, $\alpha$-hydroxybutyric acid, $\beta$ hydroxybutyric acid, $\gamma$-hydroxybutyric acid, p-hydroxyphenylacetic acid, $\alpha$-ketoglutaric acid, lactamide, D-lactic acid methyl ester, L-lactic acid, L-malic acid, succinic acid monomethyl ester, propionic acid, pyruvic acid, succinamic acid, succinic acid, $\mathrm{N}$-acetyl-L-glutamic acid, L-alaninamide, D-alanine, L-alanine, L-alanyl glycine, L-asparagine, L-serine, putrescine, 2,3-butanediol, glycerol, thymidine 5'-monophosphate, D-fructose 6-phosphate, $\alpha$-D-glucose 1-phosphate, D-glucose 6-phosphate or DL- $\alpha$-glycerol phosphate.
The cellular fatty acids $(\geqslant 1 \%)$ are iso- $\mathrm{C}_{13: 0}, \mathrm{C}_{14: 0}$, iso$\mathrm{C}_{14: 0}$, iso- $\mathrm{C}_{15: 0}$, anteiso- $\mathrm{C}_{15: 0}, \mathrm{C}_{16: 1} \omega 7 c$ alcohol, iso- $\mathrm{C}_{16: 0}$, $\mathrm{C}_{16: 1} \omega 11 c, \mathrm{C}_{16: 0}$, iso- $\mathrm{C}_{17: 1} \omega 10 c$ and iso- $\mathrm{C}_{17: 0}$. The predominant menaquinone is MK-7. The cell wall contains meso-diaminopimelic acid. The major polar lipids are diphosphatidylglycerol and phosphatidylglycerol. The DNA $\mathrm{G}+\mathrm{C}$ content is $40.8 \mathrm{~mol} \%\left(T_{\mathrm{m}}\right)$.

The type strain is CCBAU $05776^{\mathrm{T}}\left(=\mathrm{LMG} 25492^{\mathrm{T}}=\right.$ HAMBI $3097^{\mathrm{T}}$ ), isolated from the inner tissues of soybean roots from Hebei Province, China.

\section{Acknowledgements}

This work was financed by the National Natural Science Foundation of China (project no. 30970004, 30870004) and Agricultural Scientific Achievement Transformation of Ministry of Science and Technology (2008GB23600460) and the Innovative Project of SKLAB (2009 SKLAB05-1). We would like to thank Professor J. P. Euzéby for his suggestion on the spelling of the specific epithet. W.F.C. thanks Margaret R. Ruzicka, Dr C. Appunu and Professor E. T. Wang for their polishing of the manuscript.

\section{References}

Arkhipova, T., Veselov, S., Melentiev, A., Martynenko, E. \& Kudoyarova, G. (2005). Ability of bacterium Bacillus subtilis to produce cytokinins and to influence the growth and endogenous hormone content of lettuce plants. Plant Soil 272, 201-209.

Bai, Y., D’Aoust, F., Smith, D. L. \& Driscoll, B. T. (2002). Isolation of plant-growth-promoting Bacillus strains from soybean root nodules. Can J Microbiol 48, 230-238.

Bartholomew, J. W. \& Mittwer, T. (1950). A simplified bacterial spore stain. Stain Technol 25, 153-156.

Chun, J., Lee, J.-H., Jung, Y., Kim, M., Kim, S., Kim, B. K. \& Lim, Y. W. (2007). EzTaxon: a web-based tool for the identification of prokaryotes based on $16 \mathrm{~S}$ ribosomal RNA gene sequences. Int J Syst Evol Microbiol 57, 2259-2261.

Collins, M. D. (1985). Analysis of isoprenoid quinones. Methods Microbiol 18, 329-366.

De Ley, J. (1970). Reexamination of the association between melting point, buoyant density, and chemical base composition of deoxyribonucleic acid. J Bacteriol 101, 738-754.

De Ley, J., Cattoir, H. \& Reynaerts, A. (1970). The quantitative measurement of DNA hybridization from renaturation rates. Eur $J$ Biochem 12, 133-142.

Dong, X.-Z. \& Cai, M.-Y. (editors) (2001). Determination of biochemical properties. In Manual for the Systematic Identification of General Bacteria, pp. 364-398. Beijing: Science Press (in Chinese).

Felsenstein, J. (1985). Confidence limits on phylogenies: an approach using the bootstrap. Evolution 39, 783-791.

Guindon, S. \& Gascuel, O. (2003). A simple, fast, and accurate algorithm to estimate large phylogenies by maximum likelihood. Syst Biol 52, 696-704.

Heyrman, J., Logan, N. A., Rodríguez-Díaz, M., Scheldeman, P., Lebbe, L., Swings, J., Heyndrickx, M. \& De Vos, P. (2005). Study of mural painting isolates, leading to the transfer of 'Bacillus maroccanus' and 'Bacillus carotarum' to Bacillus simplex, emended description of Bacillus simplex, re-examination of the strains previously attributed to 'Bacillus macroides' and description of Bacillus muralis sp. nov. Int J Syst Evol Microbiol 55, 119-131. 
Jukes, T. H. \& Cantor, C. R. (1969). Evolution of protein molecules. In Mammalian Protein Metabolism, vol. 3, pp. 21-132. Edited by H. N. Munro. New York: Academic Press.

Kroppenstedt, R. M. (1982). Separation of bacterial menaquinones by HPLC using reverse phase (RP18) and a silver loaded ion exchanger as stationary phases. J Liq Chromatogr 5, 2359-2367.

Kuisiene, N., Raugalas, J., Spröer, C., Kroppenstedt, R. M. \& Chitavichius, D. (2008). Bacillus butanolivorans sp. nov., a species with industrial application for the remediation of n-butanol. Int J Syst Evol Microbiol 58, 505-509.

Larkin, M. A., Blackshields, G., Brown, N. P., Chenna, R., McGettigan, P. A., McWilliam, H., Valentin, F., Wallace, I. M., Wilm, A. \& other authors (2007). Clustal $\mathrm{W}$ and Clustal $\mathrm{X}$ version 2.0. Bioinformatics 23, 2947-2948.

Li, J., Wang, E., Chen, W. \& Chen, W. (2008). Genetic diversity and potential for promotion of plant growth detected in nodule endophytic bacteria of soybean grown in Heilongjiang province of China. Soil Biol Biochem 40, 238-246.

Liu, B., Qiao, H., Huang, L., Buchenauer, H., Han, Q., Kang, Z. \& Gong, Y. (2009). Biological control of take-all in wheat by endophytic Bacillus subtilis E1R-j and potential mode of action. Biol Control 49, 277-285.

Logan, N. A., Berge, O., Bishop, A. H., Busse, H.-J., De Vos, P., Fritze, D., Heyndrickx, M., Kämpfer, P., Rabinovitch, L. \& other authors (2009). Proposed minimal standards for describing new taxa of aerobic, endospore-forming bacteria. Int J Syst Evol Microbiol 59, 21142121.

Marmur, J. (1961). A procedure for the isolation of deoxyribonucleic acid from micro-organisms. J Mol Biol 3, 208-218.

Minnikin, D. E., Collins, M. D. \& Goodfellow, M. (1979). Fatty acid and polar lipid composition in the classification of Cellulomonas, Oerskovia and related taxa. J Appl Bacteriol 47, 87-95.

Priest, F. G., Goodfellow, M. \& Todd, C. (1988). A numerical classification of the genus Bacillus. J Gen Microbiol 134, 1847-1882.

Rai, R., Dash, P., Prasanna, B. \& Singh, A. (2007). Endophytic bacterial flora in the stem tissue of a tropical maize (Zea mays L.) genotype: isolation, identification and enumeration. World J Microbiol Biotechnol 23, 853-858.

Rajendran, L. \& Samiyappan, R. (2008). Endophytic Bacillus species confer increased resistance in cotton against damping off disease caused by Rhizoctonia solani. Plant Pathol J 7, 1-12.
Rajendran, L., Samiyappan, R., Raguchander, T. \& Saravanakumar, D. (2007). Endophytic bacteria mediate plant resistance against cotton bollworm. J Plant Interact 2, 1-10.

Rajendran, G., Sing, F., Desai, A. J. \& Archana, G. (2008). Enhanced growth and nodulation of pigeon pea by co-inoculation of Bacillus strains with Rhizobium spp. Bioresour Technol 99, 4544-4550.

Reva, O. N., Smirnov, V. V., Pettersson, B. \& Priest, F. G. (2002). Bacillus endophyticus sp. nov., isolated from the inner tissues of cotton plants (Gossypium sp.). Int J Syst Evol Microbiol 52, 101-107.

Rijavec, T., Lapanje, A., Dermastia, M. \& Rupnik, M. (2007). Isolation of bacterial endophytes from germinated maize kernels. Can $J$ Microbiol 53, 802-808.

Ritchie, D. A., Edwards, C., McDonald, I. R. \& Murrell, J. C. (1997). Detection of methanogens and methanotrophs in natural environments. Glob Change Biol 3, 339-350.

Saitou, N. \& Nei, M. (1987). The neighbor-joining method: a new method for reconstructing phylogenetic trees. Mol Biol Evol 4, 406-425.

Sasser, M. (1990). Identification of bacteria by gas chromatography of cellular fatty acids. USFCC News 20, 16.

Schleifer, K. H. \& Kandler, O. (1972). Peptidoglycan types of bacterial cell walls and their taxonomic implications. Bacteriol Rev 36, 407-477.

Senthilkumar, M., Swarnalakshmi, K., Govindasamy, V., Lee, Y. K. \& Annapurna, K. (2009). Biocontrol potential of soybean bacterial endophytes against charcoal rot fungus, Rhizoctonia bataticola. Curr Microbiol 58, 288-293.

Stackebrandt, E. \& Goebel, B. M. (1994). Taxonomic note: a place for DNA-DNA reassociation and $16 \mathrm{~S}$ rRNA sequence analysis in the present species definition in bacteriology. Int J Syst Bacteriol 44, 846-849.

Tamura, K., Dudley, J., Nei, M. \& Kumar, S. (2007). MEGA4: molecular evolutionary genetics analysis (MEGA) software version 4.0. Mol Biol Evol 24, 1596-1599.

Wayne, L. G., Brenner, D. J., Colwell, R. R., Grimont, P. A. D., Kandler, O., Krichevsky, M. I., Moore, L. H., Moore, W. E. C., Murray, R. G. E. \& other authors (1987). International Committee on Systematic Bacteriology. Report of the ad hoc committee on reconciliation of approaches to bacterial systematics. Int J Syst Bacteriol 37, 463-464.

Yumoto, I., Hirota, K., Yamaga, S., Nodasaka, Y., Kawasaki, T., Matsuyama, H. \& Nakajima, K. (2004). Bacillus asahii sp. nov., a novel bacterium isolated from soil with the ability to deodorize the bad smell generated from short-chain fatty acids. Int J Syst Evol Microbiol 54, 1997-2001. 